Сапожникова И.С.

\title{
Социально-психологическая адаптация подростков- мигрантов как компонент безопасности муниципального образовательного пространства
}

Прочесс адаптаџии мигрантов является двусторонним, так как затрагивает обе стороны: как приезжающих и пытающихся влиться в новое для себя социальное окружение, так и постоянных жителей, которые довольно часто откровенно сопротивляются и препятствуют этому процессу. Особое внимание в прощессе адаптации мигрантов должно уделяться детям, поскольку, с одной сторонь, в одном образовательном пространстве оказываются дети с различными культурными традчциями, ценностями, стереотипами поведения, из разных сочиальных слоев, что порой препятствует установлению оптимальных взаимоотношений среди учашчихся, а с другой, - именно в период детства и юности познаются и интериоризируются высшие ценности человека, складывается его смысложизненная кониепция, формируется отношение $\kappa$ себе и другим, осваиваются различных сочичальные роли и требования, вырабатываются модели поведения.

Ключевые слова: сочиально-психологическая адаптаџия, экстремальные ситуации, миграџия, нарушение безопасности личности, безопасное образовательное пространство.

В настоящее время в отечественной психологии прочно укрепилось представление о том, что социальная адаптация должна рассматриваться как процесс, включающий в себя не только усвоение, но и активное воспроизводство индивидом общественных отношений. По мнению Д.И. Фельдштейна процессы социализации-индивидуализации (основные смысловые конструкты социальной адаптации) выступают как единый неразрывный процесс, хотя определенное доминирование социализации или индивидуализации может проявляться на определенных этапах личностного развития (теория поуровневого развития личности). Этот аспект проблемы социальной адаптации черезвычайно важен применительно к проблеме миграции в современном Российском обществе. Традиционно в отечественной психологии считается, что показателем успешной адаптации человека, в том числе конечно же и подростка, является его социализация, то есть успешное усвоение социального опыта, требований и ожиданий социума в новых условиях жизни. Индивидуализация же - стремление человека понять свое «Я» - не рассматривается как важнейший компонент социальной адаптации мигранта, которому зачастую, для достижения «психологического» комфорта в новом жизненном мире, приходится перестроить не только внешние атрибуты жизни и начать соответствовать требованиям новому культурному контексту, но и качественно изменить свои смысложизненные ориентации, общую жизненную направленность, пересмотреть свою систему ценностей. Проблема социальной адаптации, применительно к условиям миграции, 
должна рассматриваться как определенный баланс между социализацией и индивидуализацией индивида, поскольку именно во взаимодествии этих важнейших составляющих личности, происходит формирование личностного как смысложизненной концепции, которая понимается как индивидуальная обобщенная система взглядов на цели, процесс и результат своей жизни. В основе этой концепции лежат ценности и потребности, отношения и конструкты конкретной личности. Смысложизненная концепция начинает складываться к подростковому возрасту, может изменяться и трансформироваться на протяжении жизни человека, но на определенном этапе онтогенеза является достаточно устойчивой (Столин В.В., Столина Т.В.). Таким образом, можно сказать, что смысложизненная концепция - это стержневая направленность личности, ее смысл жизни. Она содержит в себе те жизненные смысловые универсалии, те ценности, которые и составляют основу личности. Понять и описать механизм социальной адаптации подростков-мигрантов возможно лишь выявив динамику и особенности смысловых образований как компонентов формирования смысложизненной концепции личности.

Однако, реалии современного мира, во многом изменили, и затруднили традиционную логику подростковой адаптации. Межнациональные конфликты и войны, кризис политической власти, рыночная экономика вызвали силтный накал социальных проблем, негативных явлений в духовной жизни общества в целом и каждого отдельного человека. Стремление определеных слоев к национальной нетерпимости и разобщенности, обострили проблемы адаптации человека в инокультурной среде. Данные обстоятельства усугубились социальной отчужденностью молодого поколения, усиливающейся геополитической нестабильностью, накалом очагов гражданских волнений, национальных конфликтов, обуславливающих развитие процессов миграции, появление вынужденных переселенцев, детей-мигрантов, беженцев.

Процесс адаптации мигрантов является двусторонним, так как затрагивает обе стороны: как приезжающих и пытающихся влиться в новое для себя социальное окружение, так и постоянных жителей, которые довольно часто откровенно сопротивляются и препятствуют этому процессу. Особое внимание в процессе адаптации мигрантов должно уделяться детям, поскольку, с одной стороны, в одном образовательном пространстве оказываются дети с различными культурными традициями, ценностями, стереотипами поведения, из разных социальных слоев, что порой препятствует установлению оптимальных взаимоотношений среди учащихся, а с другой, именно в период детства и юности познаются и интериоризируются высшие ценности человека, складывается его смысложизненная концепция, формируется отношение к себе и другим, осваиваются различных социальные роли и требования, вырабатываются модели поведения.

Особое внимание в проблеме адаптации и ассимиляции мигрантов, занимает проблема психологической адаптации подростков, так как в этот важнейший период социализации человека, происходит формирование таких важнейших смысложизненных составляющих как ценностные ориентации, направленность личности, основы саморегуляции и самоактуализации. При нарушении закономерностей адаптации и возникновении дезадаптации, 
возникает риск деформации смысловой сферы, нарушаются процессы социализации-индивидуализации.

Фельдштейн Д.И., рассматривая проблему содержания социального взросления, пишет: «Социализация в широком понимании как сложный процесс социализации-индивидуализации, объективно задаваемый социальной действительностью и социальными задачами, требованиями общества, выступает одновременно и как процесс имманентного саморазвития психики и личности ребенка. И результатом социализации-индивидуализации как составных содержательных моментов развития в онтогенезе является степень социальной зрелости растущего человека, т.е. накопление им в себе социального как человеческого свойства» (Фельдштейн Д.И. Социализация и индивидуализация содержание социального взросления и социальнопсихологической реализации детства // Мир психологии, 1998. № 1, с. 6-11)

Школьная дезадаптация - это социально-психологическое и педагогическое явление неуспешности ребенка в образовательной среде (обучение, референтная школьная группа, общение с учителями и т.д.), связанное с неразрешимым для ребенка конфликтом между требованиями образовательной среды и его психологическими возможностями и способностями, соответствующими его возрастному сензитивному периоду, уровню психического развития. При школьной дезаптации ребенок не может найти свое место в школьной среде, и быть принятым таким, какой он есть.

Подросток-мигрант в большей степени, чем его сверстники, живущие в нативной культуре, подвержен риску дезадаптации. По мнению Шабельникова В.К., специалиста по проблемам личностной деформации при разрушении традиционных этнических систем, «энергия личности организуется и структурируется той системой отношений, в которую каждый включен с рождения. В семейно-родовой структуре оформляются напряжения, градиенты и иерархии, определяющие мотивы и смыслы жизни людей. Личность в ее психической и даже физиологической организации, усваивает, интериоризирует и копирует в себе логику напряжений семейно-родовой системы. Эти напряжения создают мотивы, смыслы жизни и борьбу каждого индивида, рожденному и детерминированному родовой системой. Поэтому социальные революции, направленные на разрушение уже сложившихся социальных систем и отношений, всегда носят удар по психологии личности, прежде всего, в области мотивов и смыслов жизни людей» (Шабельников В.К. Психологические проблемы личности при разрушении традиционных этнических систем // Мир психологии. 2005. № 1 с. 73-74). 